\title{
Study the seasonal steroid hormones of common carp in Caspian Sea, Iran
}

\author{
Vahid Taghizadeh*, Mohammad Reza Imanpoor and Nooshin Mehdinejad
}

\begin{abstract}
In this investigation, serum steroid hormones such as testosterone (T), 17ß-estradiol (E2) and progesterone (P) in 12 female of the migratory population of Common carp (Cyprinus carpio) in southeast of Caspian Sea during a year from May 2011 to May 2012 were studied. The results of present study revealed that changes in levels of steroid hormones, (E2) and (T) were closely correlated to ovarian development. There was significant difference in level of $17 \beta$ - estradiol between autumn and winter seasons that the highest of 17- $\beta$ estradiol level was observed in autumn season. In the case of progesterone hormone, higher levels was recorded in summer season and there was significant difference between summer and spring seasons and lower level of testosterone was observed in spring season.
\end{abstract}

Keywords: Common carp, Cyprinus Carpio, Steroid hormones, Testosterone, 17ß-estradiol, Progesterone, Seasons

\section{Introduction}

Sex steroid hormones play important roles in many physiological processes, particularly in the reproduction of vertebrates. In many species of teleost, three sex steroid hormones, 17 $\beta$-estradiol (E2), 11-ketotestosterone (11-KT) and $17 \quad \alpha 20 \quad \beta$ - dihydroxy-4-pregnen-3-one (DHP) are abundantly produced in gonadal tissues under the control of pituitary gonadotropins (GTH), and are essential for critical steps of gametogenesis (Wallace \& Browder 1985; Agahama \& Yamashita 2008; Miura et al. 1991).

A major estrogen, E2, controls pivotal physiological events in female reproductive cycles in all vertebrates studied to date. The association of changes in gonadal development with plasma levels of gonadal steroids has proven to be a valuable tool for understanding the endocrine control of reproduction in teleosts. Moreover, in teleosts, vitellogenesis and final oocyte maturation are regulated by gonadotropins via steroids secreted by the Granolosa and Theca cells of developing and mature oocytes. The occurrence of steroid production in different cells of the ovary may be related to different phases of oocyte development (Shafiei Sabet et al. 2009). Cyclical changes in the reproductive hormones of teleost fishes

\footnotetext{
* Correspondence: vahid_taghizadeh54@yahoo.com

Department of Fisheries, Gorgan University of Agricultural Sciences and Natural Resources, Gorgan, Iran
}

are widely known to occur in association with reproductive cycles and have been investigated mainly to understand the mechanisms of reproductive behavior, gametogenesis, and gonadal steroidogenesis (Fostier et al. 1983; Goetz 1983). Seasonal changes in circulating levels of gonadal steroid hormones during the reproductive cycle are described for a variety of freshwater and marine teleost species (Fostier et al. 1983; Pankhurst \& Carragher 1991). With the onset of oocyte maturation/ovulation the estrogen level, which is low in the postvitellogenic ovary, undergoes a further significant reduction in several species including the catfish. Fossilis and Clarias batrachus (Joy et al. 1998) indicating a shift in steroidogenesis.

During vitellogenesis an increase in plasma estrogen levels, mainly estradiol that correlates with the growth of vitellogenic oocytes has been observed in many species. In the tilapia Sarotherodon aureus (now Oreochromis aureus), the initiation of spawning by increasing water temperature is followed by a rise in testosterone levels (Katz \& Eckestein 1974). Although it has been ascertained in cyprinids that final oocyte maturation and ovulation are induced by a preovulatory gonadotropin surge, little information on the plasma and gonadal changes in steroid hormone levels during the reproductive cycle in Cyprinus carpio is known.

\section{Springer}

(c) 2013 Taghizadeh et al.; licensee Springer. This is an Open Access article distributed under the terms of the Creative Commons Attribution License (http://creativecommons.org/licenses/by/2.0), which permits unrestricted use, distribution, and reproduction in any medium, provided the original work is properly cited. 
Table 1 Seasonal changes in steroid hormones of Cyprinus carpio

\begin{tabular}{lllll}
\hline Winter & Autumn & Summer & Spring & $\begin{array}{l}\text { Seasons } \\
\text { Hormone }\end{array}$ \\
\hline $0.46 \pm 0.23^{\mathrm{ab}}$ & $0.62 \pm 0.04^{\mathrm{ab}}$ & $0.71 \pm 0.02^{\mathrm{a}}$ & $0.42 \pm 0.01^{\mathrm{b}}$ & progesterone \\
$30 \pm 14.25^{\mathrm{a}}$ & $247.73 \pm 134.14^{\mathrm{a}}$ & $110.60 \pm 48.27^{\mathrm{ab}}$ & $110.43 \pm 80.13^{\mathrm{ab}}$ & $17-\beta$ estradiol \\
$0.56 \pm 0.08^{\mathrm{a}}$ & $0.71 \pm 0.18^{\mathrm{a}}$ & $0.72 \pm 0.02^{\mathrm{a}}$ & $0.05 \pm 0.0^{\mathrm{b}}$ & Testosterone \\
\hline
\end{tabular}

Means with the same superscript letters at the same row are not significantly different $(P>0.05)$.

The aim of this work was to investigate the seasonal cycle of the gonadal steroids testosterone (T), 11ketotestosterone (11-KT), and 17b-estradiol (E2) in the serum of wild-caught populations of Cyprinus carpio from the southern Caspian Sea.

\section{Materials and methods}

\section{Broodstock preparation}

The study was conducted between May 2011 and May 2012. 12 specimens of female Common carp were captured from southeast of Caspian Sea during year and transported to Central Laboratory of Gorgan University of Agricultural Science and Natural Resources, Gorgan, Iran. In each season, 3 specimens of female fish were captured. Total weight $(937.08 \pm 216.5 \mathrm{~g})$ and total length $(42.08 \pm 3.5 \mathrm{~cm})$ of the fishes were measured.

\section{Measurement of serum steroid levels}

The blood samples were taken from caudal vein with a nonheparinized syringe and centrifuged for $10 \mathrm{~min}$. at $3000 \times \mathrm{g}$, and then serum was stored at $-20^{\circ} \mathrm{C}$ until analyzed.

\section{Statistical analysis}

Data were statistically analyzed by analysis of variance (ANOVA) using the General Linear Models procedure coupled with Duncan's multiple range test in SPSS software (Ver. 16.0).

\section{Results}

The mean values and standard deviation of the steroid hormones of Cyprinus carpio are summarized in Table 1.

Steroid hormones analysis during four seasons showed that there was no significant differences in level of $17 \beta-$ stradiol among spring, autumn and also between autumn and winter seasons and higher level belong to autumn season. There was significant difference in level of testosterone among spring and autumn seasons. Also level lower of progesterone was observed in summer season.

Level of $17 \beta$, estradiol hormone in spring, summer, autumn and winter seasons were $110.43 \pm 80.13,110.60 \pm$ 48.27, $247.73 \pm 134.14$ and $30.13 \pm 14.25$ (Figure 1). There was significant difference in level of $17 \beta$ - estradiol between autumn and winter seasons that the highest of $17-\beta$ estradiol level was observed in autumn season.

In the present study level of testosterone hormone in spring, summer, autumn and winter seasons were $0.05 \pm$ $0.005,0.72 \pm 0.02,0.71 \pm 0.18$ and $0.56 \pm 0.08$ that higher level belong to summer season and there was significant difference in level of testosterone among spring season with summer, autumn and winter seasons (Figure 2). Also lower level of testosterone was observed in spring season.

In the case of progesterone hormone, higher levels were seen summer season and there was significant

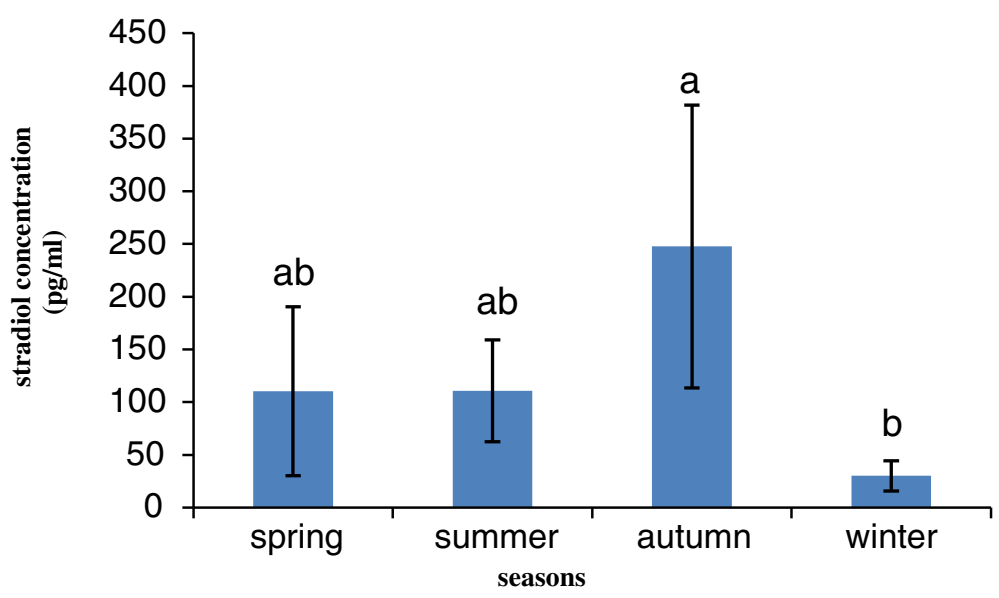

Figure 1 Stradiol hormone concentration in seasons. 


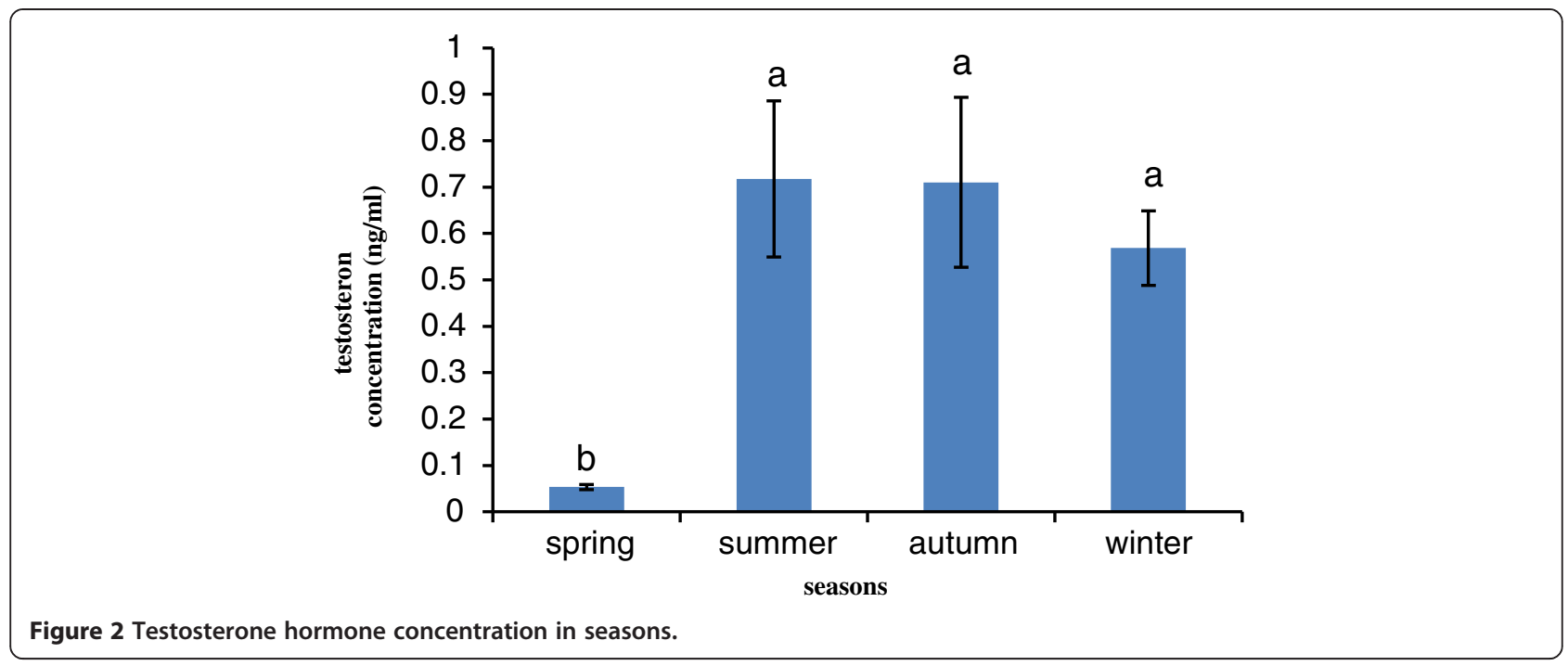

difference between summer and spring season. Levels of progesterone hormone in spring, summer, autumn and winter seasons were $0.42 \pm 0.01,0.71 \pm 0.02,0.62 \pm 0.04$ and $0.46 \pm 0.23$ (Figure 3).

\section{Discussion}

Three sex steroid hormones, 17 $\beta$-estradiol (E2), 11ketotestosterone (11-KT), and $17 \alpha, 20 \beta$, dihydroxy- 4pregnen-3-one (DHP) are well established as primary estrogen, androgen, and progestin, respectively, in teleost fish. In vitro and in vivo assays suggest that $11-\mathrm{KT}$ and E2 play primary roles in previtellogenic and growth of oocytes, respectively, whereas DHP is essential for induction of final oocyte maturation (Kazeto et al. 2011).

$17-\beta$ estradiol (E2) is secreted by both the female gonads and inter-renal tissues. In general, estradiol is responsible for stimulating vitellogenesis and is also secreted by female gonads during the pre-spawning period. Evaluation of the results in Table 1 and Figure 1 shown that there is an increase in the level of $17 \beta$ estradiol in autumn season. Estradiol is known to be secreted by the cells of the ovarian follicles that promote the development and maintenance of the female sexual characteristics. In humans this hormone (together with other hormones) is responsible for controlling the female sexual cycle. Estradiol has been reported to stimulate vitellogenesis in teleosts (Campbell \& Idler 1976; De Vlaming et al. 1980; Smith \& Haley 1988). These authors have reported an increase in plasma estradiol levels once spawning commences, and that it remains high throughout the period of oocyte growth. These observations suggest that during this phase of undetectable estradiol levels, no vitellogenesis is required during the mouthbrooding period and that some females

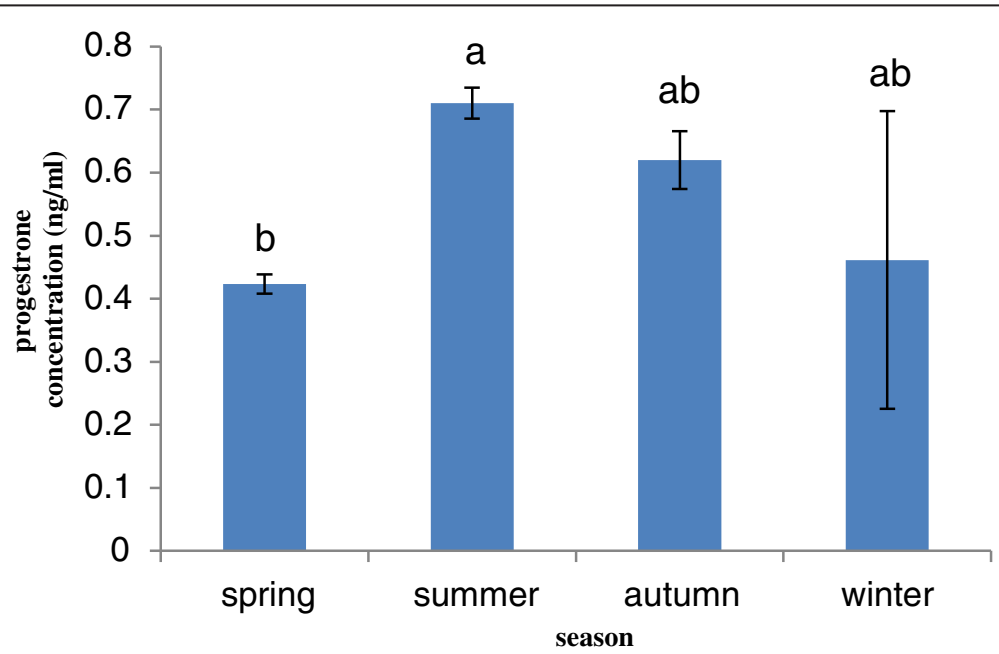

Figure 3 Progesterone hormone concentration in different seasons. 
experience gonadal recrudescence. Another possibility to be considered is that the mid-cycle decline in estradiol levels could be due to a rapid utilization of the hormone in stimulating vitellogenesis.

Rinchard et al. (Rinchard et al. 1993) Mentioned that in other teleosts such as Gudgeon (Gobio gobio), there was no decrease of E2 level during oocyte maturation; meanwhile this study has shown decreased E2 in some specimens of Cyprinus carpio.

Figure 2 shows that the highest of testosterone level was observed in summer season that this increase in testosterone in the plasma could be associated with the increase in the water temperature which occurs at the summer season. Temperature appears to be a possible cue causing testosterone to peak which leads to the gonads, and subsequently their gametes, reaching reproductive maturity.

In present results for Cyprinus carpio, showed that correspond with those for most teleosts fish and vertebrates, testosterone has been reported in the blood of a number of female teleosts. The slight increase of testosterone levels during oocyte development can be related to its role as precursor of $17-\beta$ estradiol synthesis, as a precursor of $17-\beta$ estradiol production, testosterone is available in the ovary for aromatization (Rinchard et al. 1993).

Also the highest level of progesterone hormone was observed in summer season.

During the period of summer until spring, the gonads show a relatively sharp decline in progesterone levels with some mild fluctuation corresponding with the bimodal breeding cycle. Progesterone also seems to increase in concentration as a result of the increase in water temperature that is noted during summer.

Fish are in close contact with their environment and, as a result, their physiology is influenced accordingly. However, (Sakomoto et al. 2001) have proposed that variations in blood parameters among fish could be affected by other variables such as the sampling technique, the capturing method, handle accuracy, the condition of captivity and the analysis techniques.

\section{Competing interests}

Vahid Taghizadeh: Reproduction \& culture of fish researcher. Mohammadreza Imanpoor: Reproduction \& culture of fish researcher. Nooshin Mehdinejad: Reproduction \& culture of fish researcher.

\section{Authors' contributions}

$\mathrm{VT}$ : I approved the manuscript. Ml: I approved the manuscript NM: I approved the manuscript. All authors read and approved the final manuscript.

\section{Acknowledgments}

The authors thank the aquaculture research center and Fisheries group of the Gorgan University of Agricultural Sciences and Natural resources.

Received: 17 March 2013 Accepted: 12 April 2013

Published: 30 April 2013

\section{References}

Agahama YN, Yamashita M (2008) Regulation of oocyte maturation in fish. Dev Growth Differ 50:195-219

Campbell CM, Idler DR (1976) Hormonal control of vitellogenesis in hypophysectomized winter flounder (Pseudopleuronectes americanus Walbaum). J Endocrinol 28:143-150

De Vlaming VL, Wiley HS, Delahunty G, Wallace RA (1980) Goldfish (Carassius auratus) vitellogenin: Induction, isolation, properties and relationship to yolk proteins. Com Biochem Physiol 67B:613-623

Fostier A, Jalabert B, Billard R, Breton B (1983) The gonadal steroids. In: Hoar WS, Randall DJ, Donaldson EM (eds) Fish Physiology, vol IXA. Academic, New York, pp 277-372

Goetz FW (1983) Hormonal control of oocyte final maturation and ovulation in fishes. In: Hoar WS, Randall DJ, Donaldson EM (eds) Fish Physiology, vol IXB. Academic, New York, pp 117-170

Joy KP, Senthilkumaran B, Sudhakumari CC (1998) Periovulatory changes in hypothalamic and pituitary monoamines following $\mathrm{GnRH}$ analogue treatment in the catfish Heteropneustus fossilis: a study correlating changes in plasma hormone of prowler fish. J Endocrinol 156:365-372

Katz Y, Eckestein B (1974) Changes in steroid concentrations in blood of female Tilapia aurea (teleostei, cichlidae) during initiation of spawning. J Endocrinol 95:963-966

Kazeto Y, Tosaka R, Matsubara H, ljiri S, Adachi S (2011) Ovarian steroidogenesis and the role of sex steroid hormones on ovarian growth and maturation of the Japanese eel. J Steroid Biochem Mol Biol 43:1-6

Miura T, Yamauchi K, Takahashi H, Nagahama Y (1991) Hormonal induction in all stages of spermatogenesis in vitro in the male Japanese eel (Anguilla japonica). Proc Nat Acad Sci USA 88:5774-5778

Pankhurst NW, Carragher JF (1991) Seasonal endocrine cycles in marine teleosts. In: Scott AP, Sumpter JP, Kime DE, Rolfe MS (eds) Reproductive Physiology of Fish, vol 91. Fish Symposium, Sheffield, pp 131-135

Rinchard J, Kestemont P, Kuhn ER, Foster A (1993) Seasonal changes in plasma levels of steroid hormones in an asynchronous fish the gudgeon Gobio gobio L; (Teleosti, Cyprinidae). J Endocrinol 92:168-178

Sakomoto K, Lewbart GA, Smith TM (2001) Blood chemistry values of juvenile Red pacu, Piaractus brachypomus. Vet Clinical Pathol 30:50-52

Shafiei Sabet S, Imanpoor MR, Aminian Fatideh B, Gorgin S (2009) Study on sexual maturity and levels of gonad steroid hormones in female kutum (Rutilus frisii kutum) Kamenskii, (1901) during spawning season from River Sefid-Rood of the southern Caspian Sea. J Cell Animal Biol 3:208-215

Smith CJ, Haley SR (1988) Steroid profiles of the female tilapia, Oreochromis mossambicus, and correlation with oocyte growth and mouthbrooding behavior. J Endocrinol 69:88-98

Wallace RA (1985) A comprehensive. In: Browder LW (ed) Developmental Biology. Plenum Press, New York, pp 127-177

doi:10.1186/2193-1801-2-193

Cite this article as: Taghizadeh et al:: Study the seasonal steroid

hormones of common carp in Caspian Sea, Iran. SpringerPlus 2013 2:193.

\section{Submit your manuscript to a SpringerOpen ${ }^{\circ}$ journal and benefit from:}

- Convenient online submission

Rigorous peer review

- Immediate publication on acceptance

- Open access: articles freely available online

- High visibility within the field

- Retaining the copyright to your article

Submit your next manuscript at $>$ springeropen.com 